\title{
The Influence of Brain Based Learning Approach to Students' Mathematical Problem Solving Abilities in Class V Gugus IV Kecamatan Padang Utara Padang City
}

\author{
$1^{\text {st Misra Susila }}$ \\ Mathematics and Science Faculty \\ Universitas Negeri Padang \\ Padang, Indonesia
}

\author{
$2^{\text {nd }}$ Sufyarma \\ Educational Science Faculty \\ Universitas Negeri Padang \\ Padang, Indonesia
}

\author{
$3^{\text {rd }}$ Yerizon \\ Mathematics and Science Faculty \\ Universitas Negeri Padang \\ Padang, Indonesia \\ yerizon@yahoo.com
}

\begin{abstract}
The purpose of this study was to determine whether mathematical problem solving abilities of students who get learning using the Brain Based Learning (BBL) approach are higher than students who get conventional learning. This type of research is Quasi experiment. The study population was students in class V SD gugus IV in Padang Utara sub-district. Sample selection is done by purposive sampling. The research sample was fifth grade students of Angkasa I Elementary School, consisting of two classes which were used as experimental class and control class. Research data is taken from test scores. The technique of analyzing research data through t-test. Students' mathematical abilities, especially mathematical problem solving, are still low. This happens because the implementation of learning is still teacher-centered. students tend to be passive and have not had the opportunity to express their opinions. One of the efforts made to improve students' mathematical problem solving ability is by applying the Brain Based Learning approach. An approach that optimizes brain understanding is naturally designed to learn so that learning can optimize diverse brain functions. Learning is carried out in small heterogeneous groups so that students share ideas and negotiate to unite opinions according to learning goals. The results showed that students' mathematical problem-solving abilities who learned using the Brain Based Learning approach were higher than students who learned with conventional approaches. This can be seen from the average value of the experimental class final test (54.99) higher than the average value of the control class (39.44). This is reinforced by the t-test that obtains the Sig. $0.001<0.05, H_{0}$ is rejected, meaning that BBL has a significant effect on students' mathematical problem solving abilities.
\end{abstract}

Keywords - Brain-based learning, Conventional Approach, Mathematical problem-solving

\section{INTRODUCTION}

Mathematical learning deals with ideas, abstract concepts arranged in a hierarchical and deductive reasoning. According to Van de Walle [1] that, "Mathematics is the science of something that has a pattern of order and logical order". Therefore, in mathematics learning must be gradual and continuous and sustainable so that the learning process occurs in the thinking process. Correspondingly, Gagne [2] states that in mathematics there are two objects obtained by students namely direct objects and indirect objects. Direct objects in the form of facts, skills, concepts and rules. While indirect objects include the ability to investigate and solve problems, learn independently and know how to learn.

Problem solving ability is a general goal in learning mathematics and even as the heart of mathematics (Abba) [3]. Mathematical problem solving ability is the ability of individuals to carry out a series of processes with the aim of solving a mathematical problem. This is as stated in Minister of Education Regulation No. 58 of 2014 [4] that one of the objectives of learning mathematics is the ability to solve problems. But until now the problem solving ability of students in Indonesia is still relatively low, this can be seen from the report of The Trends in International Maths Science Stydy (TIMSS). In 2007 [5], TIMSS reported that Indonesia was ranked 36th out of 49 countries with an average score of 397 , while in 2011 Indonesia was ranked 38th out of 42 countries with an average score of 386, and in the Year 2015 Indonesia ranks 44th out of 49 countries with a score of 397. According to Syaiful, et al. [6] the low ability of students' mathematical problem solving is caused by several factors: 1) learning approach factors, learning approaches used less develop problem solving abilities: 2) factors of learning habits, students are accustomed to learning by memorizing concepts, steps and procedures, this method does not train students' mathematical problem-solving abilities. The benefits of problem solving according to Fauzan [7] include: (1) Students will learn there are many ways to solve a problem; (2) Students are trained to explore, think comprehensively, and reason logically; (3) Develop the ability to communicate and shape social values through group work; (4) Students will look more 
active in learning and will express ideas more often; (5) Students have more opportunities to use and demonstrate their knowledge and mathematical skills; and (6) the confidence of students in learning mathematics increases. Therefore, the ability to solve problems in students should be instilled and familiarized from an early age. If students have good problem solving skills, students will have good analytical power to be applied in various situations.

Hudojo [8] stated "Instructions for systematic steps to solve problems are 1) Understanding of the problem, 2) Planning for problem solving, 3) Implementing problem solving planning, and 4) Looking back at the settlement". Furthermore Polya [9] and Kirkley [10] stated that to solve a problem there are four steps that can be done, namely (1) Understanding the problem, namely determining (identifying) what (data) is known, what is asked (unknown); (2) Planning the solution, which is checking whether it knows other related problems, linking it with a theorem that might be useful; (3) Implementing the plan, namely implementing the settlement plan, checking the truth of each step and proving that the steps are correct; (4) Look back, which is to re-examine the results that have been achieved, check the results, check the arguments, find the results in other ways, and use the results or methods found to solve other problems.

The success of students in capturing mathematics material, can be influenced by the approach used by the teacher during the learning process at school. The teacher must determine and choose the appropriate model, strategy, method and technique in order to engage students actively in learning, so that learning can take place well and attract students. According to Walle [1] "Students must understand mathematics and must be active in developing understanding. Understanding in mathematics cannot be translated into passive students. Students who are passive and closed will reduce their absorption and understanding. Understanding is the result of the form of student participation in working on mathematics. In order for students to be more active in the learning process, one effective approach can be used is learning that optimizes the workings of the brain, which is a brain-based approach.

Awolola [11] states that Brain Based Learning (BBL) is student-centered learning and the teacher is only a facilitator whose role is to support students' cognitive abilities. Brain-Based Learning is a learning that optimizes the work of the human brain (Jensen) [12]. Brain-Based Learning can facilitate all students with different levels of intelligence summarized in the same learning style and student-centered. This is consistent with the opinion of Wilson \& Spears [13] who stated that Brain Based Learning is a comprehensive approach to learning based on the work of the brain that suggests our brain works naturally. Thus it can be concluded that the learning in Brain Based Learning is emphasized to Student Centered. Students can be more active in the learning process in class so that they can develop the ability to solve mathematical problems they face. According to Caine \& Caine [14] the main purpose of $\mathrm{BBL}$ is to direct learning from just memorizing into meaningful learning. Brain Based Learning itself is defined as a student-centered way of learning by utilizing all brain functions and recognizing that not all students can learn the same way.

The Brain-Based Learning steps are as follows. 1) Pre-exposure, At this stage teachers display concept maps, convey learning objectives and some apperception questions. 2) Preparation, this preparation phase is the initial stage of the implementation of learning, the teacher can associate the material with everyday events. 3) Initiation and acquisition, at the initiation and acquisition stage, the teacher provides problems that students work in groups, so that efforts to improve students' mathematical problem solving abilities will occur at this stage. 4) Elaboration, at this elaboration stage the brain is given the opportunity to sort, investigate, analyze, test and deepen learning. Students will discuss ways or strategies used to solve problems with group members. Then reveal the results of the discussion to all class members for input or rebuttal. In this stage, efforts to improve mathematical problem solving skills are carried out. 5) Incubation and memory formation, at this stage students rest their brains for a while while listening to music or brain-gym. Then students solve problems that are relatively easy. 6) Verification or Confidence Check, at this stage the teacher checks the students' understanding of the material again. 7) Celebration and Integration, at this stage students together with the teacher conclude the material just learned. Then a small celebration is given for the success of learning on the day's learning (Jensen,) [12]

The advantages of this Brain Based Learning approach are 1) Providing a new thought about how the brain works; 2) Pay attention to the natural work of the learning brain in the learning process; 3) Creating a learning climate where students are respected and supported; 4) Avoid the expiration of brain work; 5) Can use various models in the learning process. In addition, according to various studies that have been conducted, it is proven that students who learn using the Brain-Based Learning approach show better results than students who are given learning with conventional approaches. The study by Heru Sukoco, et al., [15] titled "The Effect of Brain Based Learning Approaches on Mathematical Communication and Self-Effecacy Ability of High School Students" and Rully Febrayanti [16] with the title "Application of Learning-Based Brain Based Learning Approaches in Mathematics Learning for Improving the ability of mathematical connections Students of SMAN 1 Tanjung Pandan Belitung 'conclude that BBL can improve students' learning abilities and outcomes. Thus it is expected that using Brain-Based Learning students' mathematical problem solving skills can also develop optimally.

\section{Methods}

This type of research is Quasi Experimental Disign because not all variables that appear in experimental conditions can be strictly regulated and controlled. The research design used was The Nonequivalent Pretest-Posttest Control Group Design (Lestari) [17], because this study wanted to know the effect of a treatment on a variable. In this study the treatment given to the experimental class is a Brain Based Learning approach to students' problem solving abilities. While the control class uses a conventional 
approach. The study was conducted in Elementary School IV in Padang Utara Sub-District, Padang City, conducted in February - March 2018. The object studied was grade V elementary school students. Sampling was done by purposive sampling, purposive sampling was based on specific objectives or specific considerations (Joseph) [18]. The data in this study were obtained from the test results of students' problem solving skills. Data collection techniques through the results of pretest and posttest. Data analysis techniques using test results analysis techniques using t-test.

\section{DISCUSSION}

Data on mathematical problem solving abilities in this study were obtained through initial tests (pretest) and final tests (posttest) in each experimental class and control class. This mathematical problem solving ability test is in the form of a written test in the form of 5 questions. After the calculation is obtained, the results of the test students' problem solving ability and the control class are shown in Table I.

TABLE I. DATA ANALYSIS RESULTS OF STUDENTS MATHEMATICAL PROBLEM SOLVING ABILITY IN THE SAMPLE CLASS

\begin{tabular}{|l|l|l|l|l|l|l|}
\hline Class & Result & $\mathbf{N}$ & $\overline{\boldsymbol{x}}$ & $\boldsymbol{X}_{\min }$ & $\boldsymbol{X}_{\max }$ & $\overline{\boldsymbol{g}}$ \\
\hline Experiment & Pretest & 31 & 26.90 & 8 & 48 & \multirow{2}{*}{0.50} \\
\cline { 1 - 6 } & Pot-test & 31 & 54.99 & 35 & 78 & \\
\hline Control & Pretest & 32 & 38.13 & 5 & 80 & \multirow{2}{*}{0.20} \\
\hline & Post-test & 32 & 39.44 & 5 & 80 & \\
\hline
\end{tabular}

TABLE II. TEST RESULT KOLMOGOROV SMIRNOV

\begin{tabular}{|l|l|l|}
\hline \multirow{2}{*}{ Class } & \multicolumn{2}{|l|}{ Significant } \\
\cline { 2 - 3 } & Pretest & Posttest \\
\hline Experiment & 0.113 & 0.105 \\
\hline Control & 0.220 & 0.110 \\
\hline
\end{tabular}

Before doing the t-test, the assumption of normality of each data must be fulfilled first and have a homogeneous variance according to Sudjana [19]. Can be done using the Kolmogorov Smirnov Test.

TABLE III. TEST RESULT LEVENE

\begin{tabular}{|l|c|c|}
\hline \multirow{2}{*}{ Class } & \multicolumn{2}{|c|}{ Significant } \\
\cline { 2 - 3 } & Pretest & Posttest \\
\hline Experiment & \multirow{2}{*}{0.001} & 0.019 \\
\hline Control & & \\
\hline
\end{tabular}

Levene test is done to find out the data has a homogeneous variance. For the initial test and final test data based on Table 2 it is known that the overall probability of the Kosmogorov Smirnov Test is more than the 0.05 significance level so that $H_{0}$ is accepted. That is, all data is normally distributed.

For Homogeneity Test performed by Levene Test, based on what is shown in Table 3 for the pretest obtained the value of Sig. $0.001<0.05$ while for posttes the Sig value is obtained. $0.019<0.05$ so that overall less than the significance level 0.05 means that both sample groups have the same or homogeneous variant. The following is the t-test hypothesis to prove the effect of the Brain Based Learning approach on mathematical problem solving abilities.

\section{TABLE IV. RESULT OF T-TEST HYPOTHES}

\begin{tabular}{|l|l|l|l|l|}
\hline Class & $\mathrm{N}$ & $\bar{x}$ & Sig. & Information \\
\hline $\begin{array}{l}\text { Experi } \\
\text { ment }\end{array}$ & 31 & 55.10 & \multirow{2}{*}{0.001} & H0 is rejected \\
\cline { 1 - 2 } Control & 32 & 39.44 & & \\
\hline
\end{tabular}

Based on Table 4, the Sig. smaller than the 0.05 level, the null hypothesis is rejected. This means that there is a significant average difference between students who use the Brain Based Learning approach from students who use conventional approaches. The average final test score of students' mathematical problem solving using the BBL approach is higher than for students who use conventional approaches.

In learning with the BBL approach, before starting new material students are given pictures or examples related to everyday life so as to create a sense of meaning and are interested in learning more. The BBL approach requires students to be more active because students are given control to manage learning independently. Students are challenged to be able to identify various problems and are able to find solutions based on knowledge or concepts that have been obtained in previous learning. And more importantly the BBL approach is student-centered.

Unlike the conventional approach that characterizes teacher-centered learning. This approach is based on behavioristic views. Students tend to be passive because they only listen to lectures from the teacher and get concepts that have been made. The teacher only tries to move his knowledge so that students will not be able to generate their potential optimally and have an impact on learning achievement that is achieved less than the maximum.

Hypothesis testing results show that students' mathematical problem-solving abilities that use the BBL approach are higher than students who use conventional approaches. Besides that, the improvement of students' problem solving ability with BBL approach can be categorized as moderate with $\mathrm{N}$-gain 0.50 while students with conventional approaches are categorized as low with $\mathrm{N}$-gain 0.20

The application of brainstorming learning can encourage students to be more active in gaining concepts that can be used in problem solving. In this way the learning received by the students was more meaningful. The results showed the majority of students in the experimental class were able to solve the problem in accordance with the problem solving indicators. This is because students gain knowledge from their own experience through the BBL approach so that the acquired knowledge is more meaningful and can be applied directly by students. This fact is supported by research conducted by Heru Sukoco, et al. [14] concluded that learning with a BBL approach can improve mathematical communication skills and self-efficacy of students and Rully [15] concluded that the mathematical ability of students to improve their connection with the application of BBL. Based on these results proved the BBL approach can improve student learning outcomes. 


\section{CONCLUSION}

Based on the results of the study, it can be seen that the average value of students' mathematical problem solving ability in the experimental class uses BBL higher than the average value of the control class using conventional approaches.

Learning with the BBL approach should be applied on a broader and deeper scale as an alternative to develop students' mathematical problem solving abilities. Learning that is done cooperatively and collaboratively through small groups or circular learning patterns should be practiced in mathematics learning. Through a circular pattern, students who have relatively high mathematical abilities can further strengthen their understanding and beliefs. Whereas for students who have low mathematical abilities will gain a better understanding of peer explanations that may be in a language that is easier to understand.

\section{REFERENCES}

[1] Van de Walle. John, Matematika Sekolah Dasar dan Menengah. Jakarta: Gelora Aksara Pratama, 2008.

[2] Gagne. Robert M, Kondisi belajar dan teori pembelajaran (terjemahan Munandir), PAU Dirjen Dikti Depdikbud. Jakarta, 1989.

[3] Abba. N, Pengembangan Perangkat Pembelajaran Matematika Berorientasi Model Pembelajaran Berdasarkan Pemecahan Masalah (Problem-Based Instructure), Surabaya:Program Pascasarjana Universitas Negeri Surabaya, 2000.

[4] Depdiknas, Permendiknas No. 2 tentang SI dan SKL, Jakarta: SinarGrafika, 2006.

[5] Trends in International Mathematics and Science Study (TIMSS) Result [online] tersedia: http://nces.ed.gov/timss/tabel 1 1.asp.

[6] Syaiful, Kusumah, Yaya S., Sabandar, Yozua, Darhim, "Peningkatan Kemampuan Pemecahan Masalah Matematis Melalui Pendekatan Matematika Realistik", Jurnal disajikan dalam seminar nasional: Yogyakarta, 2011.

[7] Fauzan. Ahmad, Modul I Evaluasi Pembelajaran Matematika. Pemecahan Masalah Matematika, Evaluasi matematika.net: Universitas Negeri Padang, 2012.

[8] Hodojo. Herman, Pengembangan Kurikulum dan Pembelajaran 6 Matematika, Malang: UM Press, 2005.

[9] Polya, How to Solve It, $2^{\text {nd }}$ ed, Princenton University Press, 1985. 